\title{
IDENTIFIKASI AKTIVITAS PERIKANAN MERUSAK DI TELUK SAWAI
}

\author{
(Identification of Destructive Fishing in Sawai Bay)
}

\author{
Frederik Willem Ayal", James Abrahamsz, dan Reinhardus Pentury
}

\begin{abstract}
Jurusan Manajemen Sumberdaya Perairan Fakultas Perikanan dan Ilmu Kelautan Universitas Pattimura eddy.kakha@gmail.com,abrahamsz_amq@yahoo.com,rpentury0508@gmail.com

Corresponding author*
\end{abstract}

\begin{abstract}
ABSTRAK: Aktivitas perikanan merusak atau Destructive Fishing adalah kegiatan penangkapan ikan dengan menggunakan bahan, alat atau cara yang merusak sumberdaya ikan maupun lingkungannya, seperti menggunakan bahan peledak, bahan beracun, strum, dan alat tangkap lainnya yang tidak ramah lingkungan (KepMen KP Nomor 114, 2019). Aktivitas ini masih terjadi pada perairan Maluku, termasuk di Teluk Sawai. Penelitian ini bertujuan untuk mengidentifikasi bentuk-bentuk penangkapan ikan yang merusak pada perairan Teluk Sawai serta memberikan rekomendasi pengendalian untuk mereduksi aktivitas perikana. Yang merusak. Penelitian ini dilakukan pada Januari-Juni 2020 di Teluk Sawai. Pengumpulan data menggunakan metode purposive interview, sedangkan data dianalisis secara deskriptif. Hasil penelitian menunjukkan bahwa pada perairan Teluk Sawai, teridentifikasi tiga aktivitas perikanan merusak yaitu penangkapan ikan menggunakan bom/bahan peledak, penangkapan ikan menggunakan bahan beracun dan aktivitas penambangan karang. Empat strategi pengendalian direkomendasikan sebagai upaya mereduksi aktivitas perikanan merusak di perairan Teluk Sawai ke depannya.
\end{abstract}

Kata Kunci: perikanan merusak, penangkapan ikan, ikan karang, strategi pengendalian, Teluk Sawai

\begin{abstract}
Destructive fishing activities are fishing activities using materials, tools or means that damage fish resources and their environment, such as using explosives, toxic materials, strum, and other fishing gear that are not environmentally friendly (Marine and Fisheries Ministerial Decree Number 114, 2019). This activity still occurs in Maluku waters, including in Sawai Bay. The study aims to identify destructive forms of fishing in the waters of Sawai Bay and provide control recommendations to reduce the destructive fishing activity. The study was conducted in January-June 2020 in Sawai Bay. Data collection uses the purposive interview method, while the data is analyzed descriptively. The results showed that in the waters of Sawai Bay, three destructive fishing activities were identified, namely fishing using bombs/explosives, fishing using toxic materials and coral mining activities. Four control strategies are recommended as an effort to reduce destructive fishing activity in the waters of Sawai Bay in the future.
\end{abstract}

Keywords: destructive fishing, fishing, reef fish, control strategies, Sawai Bay

\section{PENDAHULUAN}

Secara administratif, Teluk Sawai terletak di Kabupaten Maluku Tengah dan terdapat dua kecamatan yang negeri-negerinya (desa) berada dan melakukan aktivitas pemanfaatan, khususnya aktivitas pemanfaatan ikan karang ekonomis penting di Teluk Sawai. Teluk Sawai terletak pada bagian Utara Pulau Seram yang 
memiliki luas perairan $1.100 \mathrm{~km}^{2}$ dan terdiri atas 13 negeri yang berada di sekitarnya. Teluk Sawai juga berdekatan dengan Taman Nasional Manusela yang merupakan wilayah konservasi kehutanan. Pada kawasan ini terdapat banyak spesies flora dan fauna yang dilindungi (Mustofa, et al., 2017). Tingginya aktivitas masyarakat yang menunjukan tren degradasi lingkungan yang menjadikan pemerintah berusaha untuk melindungi wilayah Teluk Sawai (Firmansyah, $d k k ., 2018)$.

Mata pencaharian utama sebagian besar masyarakat di sekitar Teluk Sawai adalah menangkap ikan. Ayal (2009) menjelaskan bahwa bercocok tanam hanya menjadi mata pencaharian tambahan bagi masyarakat yang berada dan melakukan aktivitas penangkapan ikan karang di perairan Teluk Sawai. Kondisi ini dipicu oleh prospek perikanan karang Teluk Sawai yang cukup baik untuk dapat dikembangkan. Tulalessy (2013) melaporkan jumlah spesies ikan karang dan ikan hias yang hidup di ekosistem terumbu karang di Seram Utara Barat sebanyak 134 spesies yang termasuk dalam 68 genus dan 32 famili. Lima puluh delapan spesies dari semua spesies ikan termasuk ikan target konsumsi yang memiliki nilai ekonomis penting, sementara 76 spesies lainnya adalah ikan hias yang tinggal di terumbu karang. Secara umum, kondisi ini menunjukkan jumlah spesies ikan hias di terumbu karang Teluk Sawai lebih tinggi dibanding ikan target konsumsi yang memiliki nilai ekonomis tinggi.

Aktivitas penangkapan ikan karang yang dilakukan pada perairan ini oleh nelayan pantai di Teluk Sawai menggunakan alat tangkap yang didominasi oleh troll line gear, gillnet dan net dengan masing-masing persentase $36 \%, 26 \%$ dan 19\% (Darmono, et al., 2017). Namun praktekpraktek penggunaan alat tangkap yang merusak juga masih terjadi. Berdasarkan KepMen Kelautan dan Perikanan 114 tahun 2019, aktivitas perikanan merusak atau Destructive Fishing adalah kegiatan penangkapan ikan dengan menggunakan bahan, alat atau cara yang merusak sumberdaya ikan maupun lingkungannya, seperti menggunakan bahan peledak, bahan beracun, strum, dan alat tangkap lainnya yang tidak ramah lingkungan (KKP, 2019). Dahuri, $d k k$. (2008) menyatakan bahwa salah satu faktor penyebab deplesi sumberdaya perikanan laut adalah kegiatan penangkapan ikan dengan menggunakan alat tangkap yang sifatnya destruktif/merusak.

Penggunaan alat tangkap yang tidak ramah lingkungan ini pada dasarnya merupakan kegiatan penangkapan ikan yang tidak legal, yang menyebabkan terancamnya kelestarian sumberdaya hayati laut, akibat kerusakan habitat biota laut dan kematian sumberdaya ikan. Nelayan di Kepulauan Spermonde meyadari bahwa aktivitas perikanan merusak itu illegal, namun hanya itu cara untuk mendapatkan hasil secara cepat, efisien dan dapat menjawab tuntutan kebutuhan ekonomi (Nurdin\&Gydehoj, 2014). Selain itu, kurangnya regulasi juga dapat menyebabkan penurunan sumberdaya terumbu karang yang parah dan mengakibatkan degradasi terumbu karang, terutama di daerah berpenduduk padat (Pet-Soede, et al., 1999).

Menurut Mustofa, et al. (2017), menemukan bahwa pada perairan Teluk Sawai telah terjadi blast fishing (pengeboman) dan menggunakan sianida sekitar tahun 2014-2015 oleh nelayan. Menurut Darmono, et al. (2017) mengatakan bahwa sebenarnya kegiatan penangkapan ikan yang merusak mulai dilakukan pada tahun 1980-1990, dengan aktivitas tertinggi terjadi pada 1998-2000. Hal tersebut yang menyebabkan tutupan karang lebih didominasi oleh pecahan karang. Selain itu, hasil diskusi kelompok dengan masyarakat nelayan di Desa Sawai dan Labuan, Maluku Tengah, menunjukkan bahwa, walaupun praktek destructive fishing telah jauh berkurang selama sepuluh tahun terakhir, namun diakui bahwa praktek tersebut masih berlangsung di wilayah Maluku, terutama di wilayah yang jauh dari akses dan pengawasan. Oleh karena itulah penelitian ini dilakukan dengan tujuan untuk mengidentifikasi bentuk-bentuk penangkapan ikan yang merusak pada perairan Teluk Sawai serta memberikan rekomendasi pengendalian dalam mereduksi aktivitas ini ke depannya.

\section{METODE PENELITIAN}

Penelitian ini dilakukan di Teluk Sawai, Kabupaten Maluku Tengah dan sejumlah negeri yang melakukan aktivitas penangkapan ikan 
karang pada perairan ini, pada bulan Januari Juni 2020. Jenis data yang digunakan dalam penelitian ini adalah data primer dan sekunder. Data primer adalah data yang dikumpulkan secara langsung (observasi) di lapangan dan wawancara purposive. Dalam hal ini, wawancara purposive ditetapkan secara sengaja oleh peneliti sesuai kriteria atau pertimbangan tertentu, seperti responden yang ramah, mudah didekati, serta diyakini dapat menjawab pertanyaan yang diajukan (Nawawi, 2005). Data sekunder telah tersusun (terkodifikasi) dalam dokumendokumen, diantaranya laporan tahunan, dokumen BPS, laporan penelitian, jurnal dan artikel ilmiah relevan. Analisis data menggunakan analisis deskriptif, yang menyajikan distribusi frekuensi secara tematik berupa tabel dan gambar/grafik (Sukaca, 2013). Analisis deskriptif ini bertujuan untuk melihat kecenderungan persepsi responden dengan variabel penelitian yang digunakan dan faktor pendorong nelayan melakukan aktivitas perikanan yang merusak.

\section{HASIL DAN PEMBAHASAN}

\section{Gambaran Umum Lokasi Penelitian}

Perairan Teluk Sawai merupakan bagian dari perairan Kecamatan Seram Utara dan Seram Utara Barat terdapat di Kabupaten Maluku Tengah Provinsi Maluku, yang telah dialokasikan sebagai Kawasan Konservasi Perairan sebagaimana tertuang dalam dokumen Peraturan Daerah Provinsi Maluku Nomor 1 Tahun 2018 tentang Rencana Zonasi dan Wilayah Pesisir dan Pulau-Pulau Kecil (RZWP3K) Provinsi Maluku. Kawasan ini juga telah ditetapkan menjadi Kawasan Konservasi di Perairan Seram Utara dan Seram Utara Barat di Provinsi Maluku melalui KepMen. KP-RI Nomor 50 Tahun 2021 (KKP, 2021). Kebijakan bertujuan untuk melindungi, melestarikan dan memanfaatkan keanekaragaman hayati laut seperti potensi perikanan, terumbu karang, padang lamun, mangrove, ikan napoleon, penyu dan lumba-lumba. Kawasan ini juga memiliki keunikan fenomena alam dan berpeluang besar untuk menunjang pengembangan wisata perairan yang berkelanjutan.
Potensi perikanan pada perairan ini juga menjadi fishing ground bagi 13 negeri di sekitarnya. Sebagian besar masyarakat pesisir Teluk Sawai bekerja sebagai nelayan. Nelayan memanfaatkan sumberdaya kelautan di Teluk Sawai untuk menangkap dan mencari berbagai jenis ikan dan non-ikan. Badan Pusat Statistik Seram Utara dan Seram Utara Barat menunjukkan pada tahun 2015, produksi perikanan tangkap di Seram Utara dan Seram Utara Barat masing-masing mencapai 6.199,30 ton dan 3.199,00 ton ikan. Produksi ini meningkat lebih dari $20 \%$ dibanding tahun sebelumnya, terkait dengan itu sekitar 65\% produksi didominasi komoditas ikan karang.

\section{Spesies Target Ikan Karang}

Hasil penelitian yang dilakukan oleh Mira (2021) menunjukkan sebanyak 10 spesies ikan karang ekonomis penting berhasil ditangkap dan didaratkan oleh nelayan-nelayan yang bermukim dan melakukan operasi penangkapan pada perairan Teluk Sawai (dalam periode empat bulan pengambilan data). Data hasil penelitian tersebut juga menunjukkan fluktuasi secara bulanan dari spesies-spesies ikan karang ekonomis penting yang didaratkan. Terlihat pada bulan Januari dan Februari ditemukan sekitar delapan spesies. Sementara pada bulan Maret hanya didaratkan sekitar tujuh spesies ikan karang dan pada bulan berikutnya hanya didaratkan sekitar enam spesies ikan karang.

Secara keseluruhan, selama empat bulan penelitian dilakukan, total berat ikan karang ekonomis penting yang didaratkan pada landing point tersebut mencapai $538,5 \mathrm{~kg}$. Fluktuasinya secara per bulan terlihat bahwa bulan Februari menjadi bulan dengan jumlah berat ikan karang ekonomis penting tertinggi yaitu mencapai 172,9 $\mathrm{kg}$, diikuti pada bulan Maret yang mencapai $167,6 \mathrm{~kg}$. Sementara di bulan April, total berat ikan karang ekonomis penting yang didaratkan adalah yang paling sedikit yaitu $69,5 \mathrm{~kg}$.

Berdasarkan spesies ikan karang ekonomis penting yang didaratkan selama penelitian, terlihat bahwa spesies Lethrinus harak merupakan spesies ikan karang ekonomis penting dengan kontribusi jumlah berat ikan karang terbesar yaitu 228,1 kg (Gambar 1). Kemudian, diikuti oleh spesies ikan karang 
ekonomis penting Plectropomus oligacanthus dengan total berat ikan yang didaratkan selama penelitian mencapai $104 \mathrm{~kg}$. Sementara kontribusi terkecil dari sisi berat ikan karang ditemukan pada jenis Plectropomus maculatus yang hanya menyumbangkan $1,5 \mathrm{~kg}$ berat ikan yang ditemukan juga hanya di bulan Pebruari. Diikuti juga oleh spesies Plectropomus areolatus yang juga hanya menyumbangkan berat ikan sebesar 1,9 kg, yang ditemukan hanya di bulan Maret, selama penelitian dilakukan.

\section{Daerah Penangkapan Ikan Karang}

Daerah penangkapan ikan karang menjadi salah satu elemen penting dalam suatu operasi penangkapan ikan karang (Saraswati, dkk., 2019). Letak daerah penangkapan ikan akan menentukan armada yang akan digunakan (kapal dan mesin) serta biaya operasional penangkapan. Mira (2021) juga mengungkap empat daerah penangkapan ikan karang ekonomis penting di Teluk Sawai, selama penelitiannya dilakukan. Daerah penangkapan dimaksud yaitu Perairan Lusahiit, Perairan Pulau Raja, Perairan Puputi dan Perairan Saaru Mala.

Perairan Saaru Mala menjadi daerah penangkapan ikan karang ekonomis penting yang paling banyak ditujui oleh nelayan-nelayan sekitar Perairan Teluk Sawai (Tabel 1). Tercatat sekitar 87 kali operasi penangkapan ikan karang ekonomis penting dilakukan selama penelitian ini. Diikuti oleh perairan Pulau Raja yang ditujui sebanyak 78 kali. Sementara perairan yang paling sedikit ditujui yaitu perairan Puputi yang hanya sekitar dua kali pada periode Januari-April 2020. SEA Project Indonesia (2017) melaporkan terkait daerah penangkapan ikan (tidak hanya ikan karang tetapi juga ikan pelagis) yang dilakukan nelayan di sekitar perairan Teluk Sawai dan menemukan bahwa tercatat sekitar 59 lokasi daerah penangkapan yang dimiliki sepanjang tahun.

\section{Bentuk Aktivitas Perikanan Merusak}

Nelayan-nelayan yang berada dan melakukan aktivitas penangkapan ikan karang ekonomis penting di perairan Teluk Sawai, setidaknya menggunakan tiga alat penangkapan ikan karang yang utama yaitu jaring insang dasar (bottom gill net), pancing ulur (hand line) dan panah (spear gun). Penelitian yang dilakukan SEA Project Indonesia (2017) juga melaporkan hasil survei terkait alat tangkap perikanan karang pada perairan Teluk Sawai. Selain penggunaan ketiga alat penangkapan di atas, penangkapan ikan karang ekonomis penting di wilayah perairan Teluk Sawai juga masih dilakukan dengan menggunakan alat tangkap yang merusak.

Berdasarkan data baseline report yang dilakukan oleh WWF Indonesia untuk proyek USAID SEA tahun 2017, tutupan karang di sekitar area Teluk Sawai, Maluku didominasi oleh hydroids dan sponge mencapai $24.4 \pm 4.07 \%$, sedangkan rubbles (pecahan karang) mencapai $22.3 \pm 3.68 \%$. Selain itu, hasil diskusi kelompok dengan masyarakat nelayan di Desa Sawai dan Labuan, Maluku Tengah, menunjukkan bahwa walaupun praktek destructive fishing telah jauh berkurang dalam selama sepuluh tahun terakhir, namun diakui bahwa praktek tersebut masih berlangsung di wilayah Maluku, terutama di wilayah yang jauh dari akses dan pengawasan.

Teridentifikasi berdasarkan hasil di lapangan terdapat aktivitas penangkapan merusak yaitu dengan menggunakan bahan peledak, bahan beracun dan aktivitas merusak lainnya yaitu penambangan karang. Dokumen Rencana Aksi Daerah (RAD) Penanggulangan Aktivitas Perikanan Merusak di Provinsi Maluku Tahun 2021-2025, mengkonfirmasi bahwa setidaknya ada dua aktivitas penangkapan ikan yang merusak yang terjadi di perairan Teluk Sawai. Aktivitas dimaksud yaitu penangkapan ikan dengan menggunakan bahan peledak/bom ikan dan penangkapan ikan dengan menggunakan bahan beracun.

\section{a. Penangkapan Ikan dengan Menggunakan Bahan Peledak/Bom Ikan Bahan Baku}

Bahan baku pupuk merupakan bahan peledak yang umumnya digunakan. Bahan baku ini dirakit secara tradisional dengan bahan sederhana, dengan cara menempatkan pupuk tersebut di dalam botol lalu diberi sumbu. Jenis pupuk yang digunakan yaitu ammonium nitrat $\left(\mathrm{NH}_{4} \mathrm{NO}_{3}\right)$ dan potassium nitrat $\left(\mathrm{KNO}_{3}\right)$. 


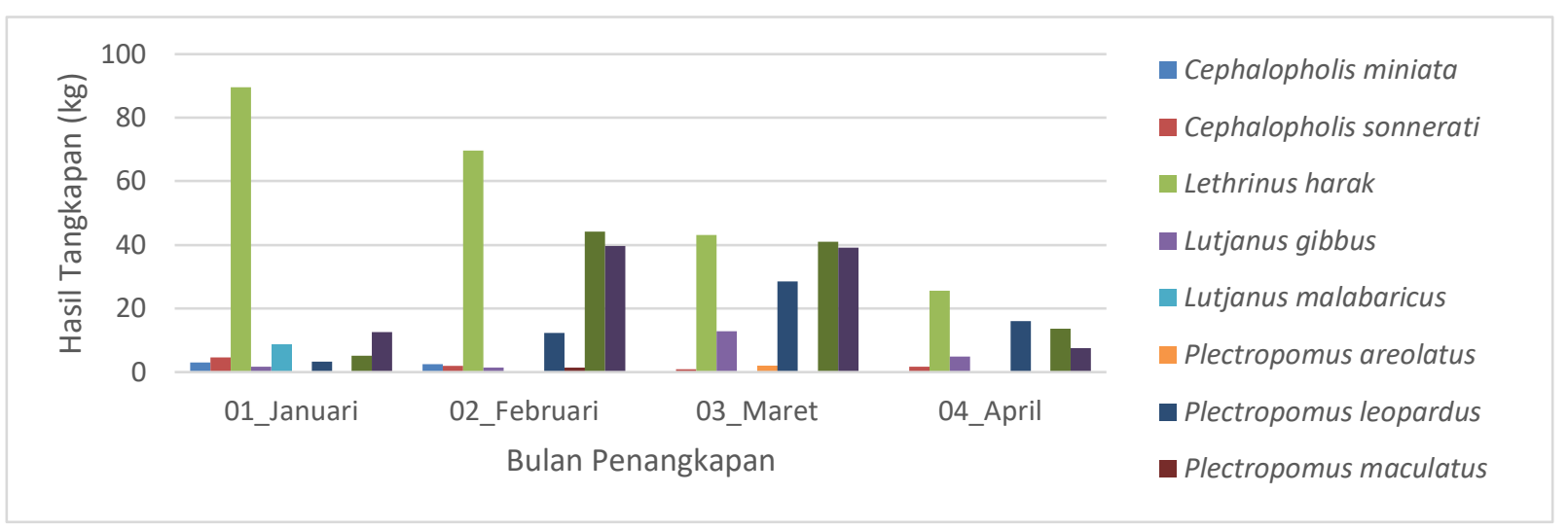

Gambar 1. Spesies Ikan Karang Ekonomis Penting yang Didaratkan Selama Penelitian

Tabel 1. Daerah penangkapan ikan karang ekonomis penting di Teluk Sawai (Mira, 2021)

\begin{tabular}{cccccc}
\hline \multirow{2}{*}{ Daerah Penangkapan Ikan } & \multicolumn{5}{c}{ Upaya Penangkapan (kali) } \\
\cline { 2 - 6 } & Januari & Pebruari & Maret & April & Total \\
\hline Perairan Lusahiit & 15 & 12 & 24 & 10 & 61 \\
\hline Perairan Pulau Raja & 21 & 13 & 34 & 11 & 78 \\
\hline Perairan Puputi & 1 & 1 & - & - & 2 \\
\hline Perairan Saaru Mala & 23 & 22 & 30 & 12 & 87 \\
\hline
\end{tabular}

\section{Dampak}

Dampak langsung dari penggunaan bahan peledak yaitu dapat merusak dan menghancurkan terumbu karang, dan bahkan dapat membahayakan keselamatan jiwa pelempar bahan peledak (Somun, 2014; Elvany, 2020). Data dari World Bank (1996) menyatakan kapasitas bahan peledak seberat 2.000 gram pada praktek penangkapan ikan menggunakan bahan peledak dapat menghancurkan lebih kurang $12,56 \mathrm{~m}^{2}$ terumbu karang. Selain itu, dapat terjadi kematian ikan target dan ikan nontarget, berikut juvenil dan biota lainnya dalam jumlah besar akibat daya ledak yang bersifat destruktif (Arianto, 2017). Dampak tidak langsung dari bahan peledak adalah berubahnya struktur tropik, modifikasi habitat, menurunnya keanekaragaman hayati perairan, dan kepunahan lokal. Habitat ikan yang rusak akan membuat nelayan harus mencari ikan ke daerah yang lebih jauh (Pontoh, 2011).

Selain menghancurkan konstruksi karang, penangkapan ikan menggunakan bahan peledak juga menghancurkan ekosistem karang. Penangkapan ikan menggunakan bahan peledak dapat menurunkan kemampuan karang untuk bertahan dari gangguan alam karena karang menjadi ringkih. Selain itu, kerusakan terumbu karang juga merugikan sektor pariwisata perairan yang mengandalkan keindahan terumbu karang. Pet-Soede, et al. (1999) memperkirakan bahwa sebuah ledakan bom ikan yang dikemas dalam botor bir, dapat menghancurkan terumbu karang seluas $5 \mathrm{~m}^{2}$. Kerusakan terumbu karang akibat penggunaan bom ikan ditandai dengan tutupan karang berupa sisa-sisa pecahan karang yang tersebar di dasar perairan (Kasnir, 2011).

\section{Pelaku}

Pada perairan Teluk Sawai, umumnya pelaku pengeboman ikan adalah nelayan lokal setempat dan/atau nelayan dari luar namun masih memiliki hubungan kekeluargaan atau hubungan sosial dengan masyarakat setempat. WWF Indonesia (2018) melaporkan hasil wawancara dengan responden informan diperoleh informasi terkait bahan-bahan pembuatan bom ikan dan biayanya secara detail, dengan rata-rata biaya bahan baku pembuatan bom minimal Rp.300.000 setiap kali melautnya. Dalam prakteknya, pelaku menggunakan alat bantu kompresor angin dan selang napas ditambah pukat sebagai alat penyamaran.

Dalam penelitian di perairan Raja Ampat, Bailey dan Sumaila (2015) menemukan bahwa kebijakan pemerintah dalam mengeliminir 
praktek perikanan merusak akan lebih mudah untuk penangkapan ikan dengan bom dibandingkan untuk yang menggunakan sianida. Hal ini dikarenakan keuntungan yang besar untuk aktivitas penangkapan ikan hias hidup membuat nelayan beralih dari penggunaan bahan peledak.

\section{b. Penangkapan Ikan dengan Menggunakan Bahan Beracun Bahan Baku}

Penangkapan ikan dengan menggunakan bahan beracun umumnya menggunakan bahan baku potassium sianida atau juga racun alami/akar tuba. Penggunaan racun alami dengan dosis yang tiggi dapat membahayakan pertumbuhan ikan (Rahim, 2017; Monica, $d k k$., 2020). Beberapa peralatan dan bahan yang digunakan untuk melakukan pembiusan yaitu botol berisi larutan potassium sianida, masker, snorkel, fin, kompressor, selang udara, serta serokan, dan wadah ikan. Ikan yang ditangkap kemudian dimasukkan ke wadah ikan dan dibawa ke kapal. Penetralan kondisi ikan dilakukan dengan membilas ikan dengan air laut hingga kondisinya normal kembali.

\section{Dampak}

Ikan yang terkena racun akan pingsan untuk beberapa waktu, sehingga kerap juga disebut pembiusan ikan. Ikan target pembiusan adalah ikan hias (ornamental fish) dan ikan karang konsumsi. Penggunaan bahan beracun pada kegiatan penangkapan ikan meningkat seiring dengan meningkatnya permintaan konsumen terhadap ikan hias dan ikan karang hidup untuk konsumsi (Muhammadiyah\&Risfaisal, 2016). Pembiusan ikan biasa terjadi di perairan dangkal, seperti di rataan terumbu karang.

Berdasarkan hasil pengawasan Direktorat Jenderal PSDKP, beberapa nelayan lokal juga kerap memanfaatkan racun alami yang berasal dari daun dan akar tuba untuk pembiusan. Bahan berbahaya lainnya yang dimanfaatkan yaitu insektisida dan tinta, sedangkan yang paling banyak digunakan oleh nelayan adalah potassium sianida. Hasil pengawasan yang dilaksanakan oleh Direktorat Jenderal PSDKP menyimpulkan bahwa kerusakan akibat pembiusan ikan hias dapat memiliki dampak buruk yang lebih besar daripada pembiusan ikan terhadap ikan karang untuk konsumsi, dan bahkan lebih besar dari dampak penangkapan ikan menggunakan bahan peledak. Hal tersebut terjadi karena titik penyemprotan untuk mendapatkan ikan hias memperhatikan arus air sehingga racun lebih banyak mengenai bagian tubuh karang. Karang bercabang (branching coral) banyak dipatahkan untuk memperoleh ikan hias yang berukuran kecil. Sedangkan pada penggunaan bahan peledak, karang dapat hancur namun masih memiliki kesempatan untuk hidup kembali. Penggunaan bius ikan menyebabkan kerusakan terumbu karang, sekaligus kematian larva dan ikan-ikan kecil. Kerugian ekonomi yang diakibatkan oleh kerusakan terumbu karang dalam jangka panjang mencapai ratusan ribu dollar Amerika Serikat per km² (Pet-Soede et al., 1999).

\section{Pelaku}

Sama seperti pelaku pengeboman ikan, pelaku aktivitas racun/bius ikan juga umumnya dilakukan oleh nelayan lokal dan/atau nelayan dari luar namun masih memiliki hubungan kekeluargaan atau hubungan sosial dengan masyarakat setempat. WWF Indonesia (2018) juga melaporkan hasil wawancara dengan responden informan dan mendapatkan informasi bahwa dalam prakteknya di Provinsi Maluku, jenis bahan bius yang digunakan adalah juga potassium sianida yang berbentuk padat/tablet, atau yang sering disebut sebagai potas. Material tersebut diperoleh dari pedagang di Kota Ambon secara tersembunyi namun juga dapat ditransaksikan di wilayah masing-masing dengan rata-rata besar biaya bahan baku pembuatan bius minimal Rp.500.000 setiap kali melautnya.

\section{c. Aktivitas Merusak Lainnya}

Aktivitas merusak lainnya yang diperoleh dalam penelitian yaitu berbagai aktivitas yang tidak termasuk kegiatan penangkapan ikan namun dilakukan terhadap ekosistem dengan cara-cara yang merusak ekosistem tersebut. Aktivitas merusak lainnya yang ditemukan pada perairan Teluk Sawai yaitu aktivitas penambangan karang. Saat observasi dilakukan, ditemukan bongkahan-bongkahan karang yang 
telah berada di darat untuk dijadikan bahan bangunan rumah maupun dijadikan semacam talud/tembok penghalang untuk aktivitas pembesaran ikan karang. Aktivitas ini memang tidak dapat dimasukkan ke dalam kategori aktivitas penangkapan ikan yang merusak. Namun dikarenakan dampaknya yang dapat merusak habitat terumbu karang terutama habitat dari ikan-ikan karang, termasuk di dalamnya ikan karang komersial, maka aktivitas ini juga terinvetarisir untuk perlu diperhatikan. Pengambilan karang dapat juga mengakibatkan abrasi pantai karena terumbu karang berfungsi untuk menahan gelombang (Sahetapy, dkk., 2017).

Hasil penelitian yang dilakukan oleh Asri dkk. (2019) menemukan bahwa praktek perikanan merusak bahkan masih terjadi di kawasan perairan Taman Nasional Taka Bonerate. Aktivitas ini dilakukan dengan menggunakan bahan peledak maupun bahan beracun. Aktivitas tersebut juga tidak dilakukan secara perorangan melainkan secara berkelompok (3-4 orang) yang dipimpin oleh seorang nahkoda.

Nurdin (2010) juga melaporkan dampak praktek perikanan merusak pada perairan Pulau Karanrang, Sulawesi Selatan bahwa hasil simulasi pemboman ikan menunjukkan setiap kemasan volume bahan peledak $150 \mathrm{ml}$ merusak terumbu karang seluas $5 \mathrm{~m}^{2}$ dan kemasan volume 5 liter dapat merusak seluas $20 \mathrm{~m}^{2}$. Sedangkan setiap penyemprotan sianida akan memberikan kerusakan langsung pada terumbu karang seluas $1 \mathrm{~m}^{2}$ namun dapat berdampak hingga $10 \mathrm{~m}^{2}$ berdasarkan pola dan kecepatan arus.

\section{Ikan-Ikan Karang Target Aktivitas Perikanan Merusak}

Pada aktivitas perikanan merusak, tidak semua spesies ikan karang target yang diuraikan sebelumnya merupakan ikan karang target. Umumnya yang menjadi target adalah ikan-ikan karang yang senang hidup secara berkelompok atau bergerombol (schooling).

Efek dari penggunaan bom dan racun akan mempengaruhi semua jenis ikan yang ada pada saat itu, termasuk biota terancam punah seperti penyu, pari, hiu dan juga habitat terumbu karang pun ikut mendapatkan dampak. Aktivitas penangkapan ikan dengan menggunakan bom ikan umumnya dilakukan untuk mendapatkan ikan ekonomis secara lebih mudah dalam keadaan mati, sedangkan penggunaan potassium sianida yang umumnya digunakan di dasar laut perairan (terumbu karang) oleh nelayan untuk mencari ikan hidup. Beberapa spesies ikan karang target aktivitas perikanan merusak yang ditemukan pada perairan Teluk Sawai adalah sebagaimana ditampilkan pada Tabel 2.

Tabel 2. Spesies ikan karang target aktivitas perikanan merusak di Teluk Sawai

\begin{tabular}{lll}
\hline Ikan Demersal & Nama Lokal & \multicolumn{1}{c}{ Nama Latin } \\
\hline Ekor Kuning & Lalosi & Caesio sp. \\
Kakap & Gaca/Silapa & Lutjanus $\mathrm{sp}$. \\
Baronang & Samandar & Syganus $\mathrm{sp}$. \\
Lencam & Sikuda/ & Lethrinus $\mathrm{sp}$. \\
& Katamba & \\
Kerapu & Garopa & Epinephelus $\mathrm{sp}$. \\
Sunu & Garopa & Cephalopholis $\mathrm{sp}$. \\
\hline
\end{tabular}

\section{Strategi Pengendalian Aktivitas Perikanan Merusak di Teluk Sawai}

Laju aktivitas perikanan merusak dapat ditekan melalui sejumlah arahan pengendalian yang dirumuskan antara lain:

a. Penyadartahuan Secara Berkala

Beberapa arahan pengendalian yang dirumuskan yaitu:

- Melaksanakan program penyadartahuan (sosialisasi, kampanye dan edukasi);

- Merancang materi KIE (Komunikasi, Informasi dan Edukasi) tentang bahaya penangkapan ikan yang merusak dan penanggulangannya;

- Meningkatkan kapasitas untuk kader penyuluh atau tokoh-tokoh masyarakat (termasuk tokoh perempuan) mengenai cara sosialisasi dalam rangka pemberantasan penangkapan ikan yang merusak.

b. Penguatan Pengawasan Aktivitas Perikanan Merusak

Beberapa arahan pengendalian yang dirumuskan yaitu:

- Melatih POKMASWAS, Kewang dan Pemerintah Desa/Negeri tentang pola pengawasan dan pelaporan kejadian 
penangkapan ikan yang merusak serta diikuti dengan peningkatan kualitas sarana pengawasan;

- Melakukan kemitraan/patroli gabungan antara penegak hukum, POKMASWAS dan Kewang. Kemitraan yang berhasil harus memadukan seluruh unsur yang terlibat di dalamnya ke dalam satu bentuk kesatuan. Hal tersebut didasarkan atas ide tentang pencegahan kejahatan multi agen. Dalam pencegahan kejahatan ini, setiap agen yang terlibat dalam penyelesaian suatu masalah memiliki peran serta masing-masing (Kusherawati \& Dermawan, 2017);

- Melaksanakan inspeksi bersama terhadap transportasi pengangkut barang dengan fokus pengawasan bahan baku peledak dan bius. Maraknya pembuatan bom untuk menangkap ikan didorong karena bahan bakunya relatif mudah diperoleh (Pontoh, 2011).

c. Penguatan Dasar Hukum Dalam Penanganan Aktivitas Perikanan Merusak

Beberapa arahan pengendalian yang dirumuskan yaitu:

- Implementasi RAD Penanggulangan Perikanan Merusak di Provinsi Maluku;

- Membentuk Forum Koordinasi Tindak Pidana (FKTP) Perikanan di Provinsi Maluku;

- Membentuk Tim/Unit Cepat Tanggap di Pemerintah Provinsi Maluku untuk memproses laporan yang diterima dari lapangan.

d. Revitalisasi Peraturan Negeri Terkait Pencegahan Aktivitas Perikanan Merusak Beberapa arahan pengendalian yang dirumuskan yaitu:

- Memfasilitasi proses penyusunan peraturan negeri dalam rangka pencegahan dan pemberantasan praktek penangkapan ikan yang merusak di skala lokal;

- Peningkatan kapasitas tentang pengelolaan perikanan berkelanjutan dan pemberantasan penangkapan ikan yang merusak terutama aturan mengenai sanksi bagi aktivitas penangkapan ikan yang merusak, modus operandi, ciri-ciri tempat penyimpanan bahan baku peledak, dampaknya dan lain-lain. Praktek perikanan merusak mulai merebak di kawasan Taman Nasional Taka Bonerate antara lain dikarenakan pudarnya pengaruh kelembagaan adat Panglima Laot dalam mengatur pengelolaan sumberdaya laut (Lampe, 2012).

\section{KESIMPULAN DAN SARAN}

Berdasarkan hasil dan pembahasan yang telah disampaikan maka dapat disimpulkan bahwa pada perairan Teluk Sawai, teridentifikasi tiga aktivitas perikanan merusak yaitu penangkapan ikan menggunakan bom/bahan peledak, penangkapan ikan menggunakan bahan beracun dan aktivitas penambangan karang. Terdapat empat strategi pengendalian direkomendasikan sebagai upaya mereduksi aktivitas perikanan merusak di perairan Teluk Sawai ke depannya. Saran yang dapat diberikan yaitu perlu penelitian lanjutan tentang dampak perikanan merusak terhadap ekosistem pesisir lainnya, mengingat aktivitas tersebut masih dilakukan.

\section{DAFTAR PUSTAKA}

Arianto, H. 2017. Urgensi Perlindungan Ekosistem Laut Terhadap Bahaya Ilegal Fishing. Lex Jurnalica 14(3): 184-191.

Asri, M., E. S. Wahyuni, A. Satria, 2019. Praktik Perikanan Destruktif (Studi Kasus Pada Taman Nasional Taka Bonerate). Sodality: Jurnal Sosiology Pedesaan 7(1): 25-33. https://doi.org/10.22500/sodality.v7i1.24782.

Ayal, F. W. 2009. Kajian Kesesuaian Perairan Pesisir Desa Sawai Kabupaten Maluku Tengah bagi Pengembangan Ekowisata. Tesis. Bogor: Sekolah Pascasarjana, Institut Pertanian Bogor.

Bailey, M. \& U.R. Sumaila. 2015. Destructive Fishing and Fisheries Enforcement in Eastern Indonesia. Marine Ecology Progress Series 530: 195-211. doi: 10.3354/meps11352.

Dahuri, R., J. Rais, S.P. Ginting, M. J. Sitepu. 2008. Pengelolaan Sumberdaya Wilayah Pesisir dan Lautan secara Terpadu. Pradnya Paramita, Jakarta. 
DOI: https://doi.org/10.30598/TRITONvol17issue2page125-134

Darmono, O.P., A. Damora, Sasi, M.M. Tamanira. 2017. Fisheries in Sawai Bay. In Baseline Report, Teluk Sawai, Maluku Province: Ecology, Fisheries, and Social Status. 47-65 p.

Elvany, A.I. 2020. Analisis Yuridis Tindak Pidana Blast Fishing yang Dilakukan Nelayan Kecil. Jurnal Hukum Unissula 37(1): 14-23.

Firmansyah, R., Estradivari, C.N.Handayani, N. Krueck, A. Mustofa, D. Saniel. 2018. Integrasi Model Konektivitas Larva dan Ukuran Optimum Zona Inti Dalam Desain Kawasan Konservasi Perairan. Majalah Ilmiah Globe 20(2): 107-116.

Kasnir, M. 2011. Analisis Aspek Ekologi Penatakelolaan Minawisata Bahari di Kepulauan Spermonde Kabupaten Pangkep, Sulawesi Selatan. Ilmu Kelautan 16(2): 61-69.

KKP. 2021. Keputusan Menteri Kelautan dan Perikanan Republik Indonesia Nomor 50 Tahun 2021 tentang Kawasan Konservasi di Perairan Seram Utara dan Seram Utara Barat di Provinsi Maluku.

KKP. 2019. Keputusan Menteri Kelautan dan Perikanan Republik Indonesia No.114/Kepmen-KP/SJ/2019 tentang Rencana Aksi Nasional Pengawasan dan Penanggulangan Kegiatan Penangkapan Ikan yang Merusak tahun 2019-2023.

Kusherawati, S. \& M.K. Dermawan 2017. Implementasi Kemitraan Dalam Pemolisian Komunitas Untuk Pencegahan Praktik Destructive Fishing (Studi Kasus Perairan Laut Maluku Utara). Jurnal Krimonologi Indonesia Vol. 1 (1):53-65

Lampe, M. 2012. Pengelolaan Sumberdaya Laut Kawasan Terumbu Karang Takabonerate dan Paradigma Komunalisme Lingkungan Masyarakat Bajo Masa Lalu. Antropologi Indonesia 33(3): 216-227.

Mira, B. 2021. Pengelolaan Sumberdaya Ikan Karang Ekonomis Penting Secara Berkelanjutan di Pesisir Teluk Sawai. Tesis. Program Pasca Sarjana Universitas Pattimura, Ambon.

Monica, D.P., M. Syaifudin, S.H. Dwinanti. 2020. Penggunaan Ekstrak Akar Tuba (Derris elliptica) Dengan Dosis yang Berbeda Dalam Pengangkutan Ikan Patin Sistem Tertutup. Jurnal Akuakultur Rawa Indonesia 8(1): 5869.

Muhammadiyah, M. \& Risfaisal. 2016. Perilaku Menyimpang Ilegal Fishing. Jurnal Equilibrium IV(1): 38-47.

Mustofa, A., D. Daniel, F. Firmasyah, N. Nubandika. 2017. Ecological Status of Sawai Bay Area. In Baseline Report, Teluk Sawai, Maluku
Province: Ecology, Fisheries, and Social Status. 16-36 p.

Nawawi, H.H., 2005. Metode Penelitian Bidang Sosial. Gajah Mada University Press, Yokyakarta.

Nurdin, N. 2010. Kajian Efektivitas Kabijakan Pada Kasus Destructive Fishing Menuju Pengelolaan Wilayah Pesisir Berbasis Masyarakat Pada Pulau-Pulau Kecil (Studi Kasus Pada Pulau Karanrang Kabupaten Pangkep Sulawesi Selatan). Jurnal Bumi Lestari 10(2): 242-255.

Nurdin, N. \& A. Grydehoj. 2014. Informal Governance Through Patron-Client Relationships and Destructive Fishing in Spermonde Archipelago, Indonesia. Journal of Marine and Island Cultures, 54-59 p.

Peraturan Daerah Provinsi Maluku Nomor 1 Tahun 2018 tentang Rencana Zonasi Wilayah Pesisir dan Pulau-Pulau Kecil Provinsi Maluku Tahun 2018-2038.

Pet-Soede, C., H.S.J. Cesar, J.S. Pet. 1999. An Economic Isuues Related to Blast Fishing on Indonesia Coral Reefs. Enviromental Conservation 26(2): 83-93.

Pontoh, O. 2011. Penangkapan Ikan dengan Bom di daerah Terumbu Karang di desa Arakan dan Wawontulap. Jurnal Perikanan dan Kelautan Tropis VII(1): 56-59. https://ejournal.unsrat.ac.id/index.php/JPKT/a rticle/view/17.

Rahim, A.W. 2017. Respons Ikan Zebra Ekor Hitam (Dascyllus melanurus) Terhadap Penggunaan Anaestesi Minyak Cengkeh Sebagai Alat Bantu Penangkapan Pada Skala Laboratorium. Marine Fisheries 8(1): 51-61.

Sahetapy, D., S. Widayati, M. Sangadji. 2017. Dampak Aktivitas Masyarakat Terhadap Ekosistem Terumbu Karang di Perairan Pesisir Dusun Katapang Kabupaten Seram Bagian Barat. TRITON: Jurnal Manajemen Sumberdaya Perairan 13(2): 105-114.

Saraswati, E., F. purwangka, W. Mawardi. 2019. Penentuan Lokasi Penangkapan Ikan Karang di Perairan Pesisir Timur Pulau Kei Besar Maluku Tenggara. Albacore 3(1): 105-124.

SEA Project Indonesia, 2017. Laporan Data Dasar Teluk Sawai, Provinsi Maluku.

Somun, H. 2014. Tinjauan Kriminologis Penggunaan Bahan Peledak Dalam Penangkapan Ikan di Desa Kalupapi Kecamatan Bangkurung Kabupaten Bangkep. Jurnal Ilmu Hukum Legal Opinion 3(2): 1-10. 
Sukaca, A., 2013. Statistik Deskriptif: Penyajian Data, Ukuran Pemusatan Data, dan Ukuran Penyebaran Data.

Tulalessy, A. H. 2013. Studi Rona Awal Lingkungan Hidup untuk Pembuatan Perkebunan Sawit PT. Sutera Sejati Indonesia di Kecamatan Seram
Utara Barat Kabupaten Maluku Tengah Provinsi Maluku. Ekosains. 2(1): 21-32.

WWF. 2018. Laporan Final: Kajian Praktek Destructive Fishing di Propinsi Maluku dan Papua Barat. WWF Indonesia - SEA Project, Jakarta. 